\title{
Hollow core in light weight concrete with pumice and silica fume
}

\author{
Amr A. Gamal ${ }^{1}$ \\ Department of Civil Engineering, BENHA University, Cairo, Egypt \\ Dr.amrgamal@hotmail.com
}

\begin{abstract}
The rise in the prices of raw material leads to the search for cheaper and lighter a raw material which reflects on the total cost of the construction project. The aim of this study was to reduce the bulk weight of concrete through partial replacement of the coarse aggregates with variable percentages of light weight aggregates (Pumice). In addition to that further investigation on reducing the bulk weight through development of hollow core in concrete cubes with variable diameters. Silica fume was added to concrete mix in order to enhance the performance of the concrete mix. Use of silica fume with $450 \mathrm{Kg} / \mathrm{m}^{3}$ cement achieved positive results in this study even with the existence of a Hollow core in concrete.

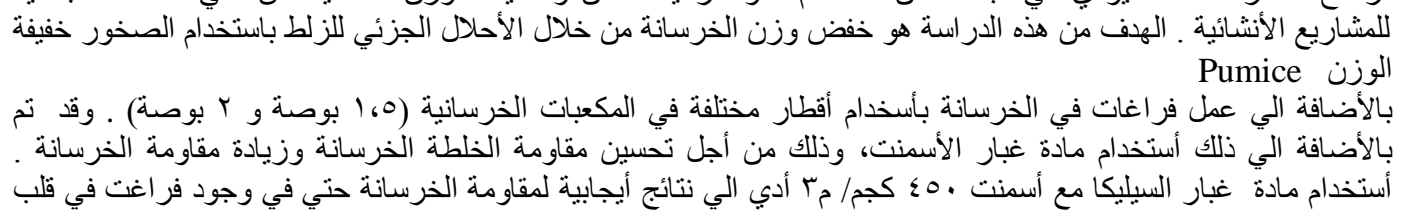

Keywords: Pumice, Cement Bricks, Lightweight aggregate, Light weight bricks

\section{INTRODUCTION}

Pumice is a low density, porous, vesicular, volcanic rock that forms during explosive eruptions. It resembles a sponge because it consists of a network of gas bubbles frozen amidst fragile volcanic glass and minerals. The size of pumice ranges from $(2 \mathrm{~mm}$ powder-65 $\mathrm{mm}$ gravel). The particle porosity can reach $85 \%$. It also has good thermal insulating properties. Pumice concrete is composed of Portland cement, pumice rock, pumice sand and water.

Pumice has been the focus of several research studies in structural and non structural applications. Several research studies have focused on mix design of light weight concrete with pumice on concrete $(1,2)$. Other research studies focused on investigation of the physical and mechanical properties of concrete with light weight aggregates. (3-8). Meanwhile other research studies focused on reducing the bulk density in the concrete matrix using polystyrene and mineral aggregates in concrete (9-12).

\section{Testing program}

The testing program was classified into two phases. The first phase with a cement content of $350 \mathrm{Kg} / \mathrm{m}^{3}$ consists of four groups, with different percentages of pumice. Replacement of pumice by volume of the crushed coarse aggregates by $(0 \%, 20 \%, 40 \%$, and $60 \%$ ) was designed to provide information about the effectiveness of pumice on reducing the bulk density of concrete. Each group was further classified into two subgroups with $0 \%$ silica fume and with $10 \%$ silica fume by weight of cement, in order to investigate the effectiveness of silica fume on strengthening the concrete matrix. See Table (1). Furthermore not only standard solid concrete cubes ( $15 \mathrm{~cm} * 15 \mathrm{~cm} * 15 \mathrm{~cm})$ and standard beams $(10 \mathrm{~cm} * 10 \mathrm{~cm} * 50 \mathrm{~cm})$ were cast, a hollow core $4 \mathrm{~cm}$ and $5 \mathrm{~cm}$ in diameter was developed in standard concrete cubes as well to investigate the effectiveness of developing a hollow core on reducing the bulk density in concrete. See Fig (1-6).

In the second phase, a cement content of $450 \mathrm{Kg} / \mathrm{m}^{3}$ was used to enhance the performance of the concrete matrix especially in concrete specimens with hollow core. This phase consists also of four groups with different percentages of pumice. Replacement of pumice by volume for the crushed coarse aggregates was done by $(0 \%, 20 \%, 40 \%$, and $60 \%)$. Also, each group was further classified into two subgroups with $0 \%$ silica fume and with $10 \%$ silica fume by weight 
of cement. Standard solid concrete cubes and beams were cast, as well as standard concrete cubes with a hollow core $4 \mathrm{~cm}$ and $5 \mathrm{~cm}$ in diameter. See Table (1). Water /cement ratio of 0.55 was used in all groups. The results were compared to reference specimens with $0 \%$ pumice.

\section{Results and Discussions \\ 3.1 Analyses of Slump Test Result \\ 3.1.1For group (1):}

The general trend among groups with $0 \%$ silica fume and $10 \%$ silica fume indicates the as the percentage of pumice increases from ( $0 \%$ to $60 \%)$, the slump value showed a continuous decrease from $(85 \mathrm{~mm}$ to $70 \mathrm{~mm}$ ) in $0 \%$ pumice. This was attributed to the high porosity level in pumice as well as the rough surface texture of pumice, which reduces workability. For the case were (10\% silica fume) was used the slump value showed a continuous decrease from (46 $\mathrm{mm}$ to $15 \mathrm{~mm}$ ) as the percentage of pumice increased from $0 \%$ to $60 \%$. The slump value in concrete specimens with $10 \%$ silica fume was lower than those encountered in specimens with $0 \%$ silica fume. This was attributed to the fine particle size of silica fume which reduces the slump value. See Fig (7).

\subsubsection{For group (2):}

For group (2) the same trend observed in specimens in group (1) was encountered in group (2). For $0 \%$ silica fume and $10 \%$ silica fume as the percentage of pumice increases from ( $0 \%$ to $60 \%$ ) the slump value showed a continuous decrease from $(80 \mathrm{~mm}$ to $65 \mathrm{~mm}$ ) in $0 \%$ pumice Subgroup. See Fig (8). For the case where $10 \%$ silica fume was used, the slump value showed a continuous decrease from (52 $\mathrm{mm}$ to $15 \mathrm{~mm}$ ); this was also attributed to the fine particle size of silica fume which effectively reduces the slump value. See Table (2).

\subsection{Analyses of Bulk Density Result}

\subsubsection{For (G 1, $0 \%$ silica fume):}

The general trend among all groups using 350 $\mathrm{Kg} / \mathrm{m}^{3}$ cement ( $\mathrm{G} 1$ ) indicates that as the size of the hollow core increases from $4 \mathrm{~cm}$ to $5 \mathrm{~cm}$, the bulk density starts to decrease from $\left(2216.3 \mathrm{Kg} / \mathrm{m}^{3}\right.$ to $2085.9 \mathrm{Kg} / \mathrm{m}^{3}$ ) with respect to solid concrete cubes with $0 \%$ Pumice which showed highest bulk density $\left(2346.7 \mathrm{Kg} / \mathrm{m}^{3}\right.$. This was due to replacement of the solid concrete sections with a hollow core voids. As the percentage of Pumice increases from $20 \%$ and up to $60 \%$, all bulk density readings starts to decrease in all groups, reaching minimum bulk density values in concrete specimens with $60 \%$ Pumice, which ranged between $2059.3 \mathrm{Kg} / \mathrm{m}^{3}$ in solid concrete cubes and $1831.1 \mathrm{Kg} / \mathrm{m}^{3}$ in hollow core concrete cubes with $5 \mathrm{~cm}$ diameter. The general behavior mentioned above was attributed to the partial replacement of the coarse aggregate with its heavy bulk with the lighter bulk of Pumice. (See Fig.9).

\subsubsection{For (G 1, 10\% silica fume):}

For concrete cubes with $10 \%$ silica fume and 350 $\mathrm{Kg} / \mathrm{m}^{3}$ cement ( $\mathrm{G} 1$ ), as the size of the hollow core increases from $4 \mathrm{~cm}$ to $5 \mathrm{~cm}$ the bulk density starts to decrease from $2198.5 \mathrm{Kg} / \mathrm{m}^{3}$ to $2094.81 \mathrm{Kg} / \mathrm{m}^{3}$. Solid concrete cubes with $0 \%$ Pumice showed highest bulk density $2361.5 \mathrm{Kg} / \mathrm{m}^{3}$. See Fig (10). It was also noted that minimum bulk density results, were registered in concrete specimens with $60 \%$ Pumice, ranging between $1964.4 \mathrm{Kg} / \mathrm{m}^{3}$ to 1804.4 . Existence of silica fume slightly affect the bulk density by a range $(0.63 \%-2.9 \%)$ compared to corresponding concrete specimens with $0 \%$ silica fume.

\subsubsection{For (G 2, $0 \%$ silica fume):}

For group 2 concrete specimens with $450 \mathrm{Kg} / \mathrm{m}^{3}$, the increase in the size of the hollow core from $4 \mathrm{~cm}$ to 5 $\mathrm{cm}$ the bulk density starts to decrease from (2112.6 $\mathrm{Kg} / \mathrm{m}^{3}$ to $1973.3 \mathrm{Kg} / \mathrm{m}^{3}$ ) with respect to solid concrete cubes for $0 \%$ Pumice which showed a bulk density $2397 \mathrm{Kg} / \mathrm{m}^{3}$. The maximum decrease in the bulk density was registered in concrete specimens with $60 \%$ Pumice, which showed a range of (1991.1 $\mathrm{Kg} / \mathrm{m}^{3}$ to $1807 \mathrm{Kg} / \mathrm{m}^{3}$. See Fig (11).

\subsubsection{For (G $2,10 \%$ silica fume):}

The same trend encountered above was encountered in this group .The general trend among all groups using $450 \mathrm{Kg} / \mathrm{m}^{3}$ cement (G 2) indicates that as the size of the hollow core increases from $4 \mathrm{~cm}$ to $5 \mathrm{~cm}$ the bulk density starts to decrease from (2222.2 $\mathrm{Kg} / \mathrm{m}^{3}$ to $2062.22 \mathrm{Kg} / \mathrm{m}^{3}$ ), with respect to solid concrete cubes with a bulk density of $2308.2 \mathrm{Kg} / \mathrm{m}^{3}$ for $0 \%$ Pumice. It was also noted that, as the percentage of Pumice increased from $20 \%$ to $60 \%$, a maximum decrease in the bulk density was registered in concrete specimens with $60 \%$ Pumice by 2074.1 $\mathrm{Kg} / \mathrm{m}^{3}$ to $1860.7 \mathrm{Kg} / \mathrm{m}^{3}$. The general behavior mentioned above was attributed to the partial replacement of the coarse aggregate with its heavy bulk with the lighter bulk of Pumice. Existence of silica fume slightly affect the bulk density by a range $(0.63 \%-1.45 \%)$ compared to corresponding concrete specimens with $0 \%$ silica fume $(5.2 \%-0.8 \%)$. See fig (12).

\subsection{Analyses of Compression Test Result \\ 3.3.1 For (G $1,0 \%$ silica fume):}

The general trend indicates that as the percentage of pumice increases from ( $0 \%$ to $60 \%)$ the compressive strength decreased from (284.4 $\left.\mathrm{Kg} / \mathrm{cm}^{2}\right)$ for $(\mathrm{G} 1,0,0)$ solid cubes to $\left(141.7 \mathrm{Kg} / \mathrm{cm}^{2}\right)$ in $\mathrm{G}(1,60,0)$ in solid cubes. The same trend was observed hollow core concrete specimens. It was noted that use of hollow core concrete specimens with diameter $(4 \mathrm{~cm})$ decreased the compressive strength from $\left(270.7 \mathrm{Kg} / \mathrm{cm}^{2}\right)$ for $(\mathrm{G} 1,0,0)$ to $(113.3$ $\left.\mathrm{Kg} / \mathrm{cm}^{2}\right)$ in $\mathrm{G}(1,60$, and 0$)$. Further increase in the diameter of hollow core from $(4 \mathrm{~cm}$ to $5 \mathrm{~cm})$ resulted 
in decrease in the compressive strength from $(154.3$ $\left.\mathrm{Kg} / \mathrm{cm}^{2}\right)$ for $\quad \mathrm{G}$ $\left(1,0\right.$, and 0) $5 \mathrm{~cm}$ specimens to $\left(105.3 \mathrm{Kg} / \mathrm{cm}^{2}\right)$ for (G 1, 60, 0). See Fig (13).

\subsubsection{For (G 1, $10 \%$ silica fume):}

The general trend indicates that use of silica fume by $10 \%$ increased the compressive strength in all silica fume specimens with respect to corresponding to $(0 \%$ silica fume) specimens. This was attributed to the fact that silica fume fills the voids in the concrete even more; this was also evident from the results obtained from bulk density results. That is in addition to the effect of silica fume in increasing the cohesion in the concrete. See Fig (14).

For concrete cubes with (10\% silica fume) it was noted that as the percentage of pumice increased from $(0 \%$ to $60 \%)$ the compressive strength decreased from $\left(367 \mathrm{Kg} / \mathrm{cm}^{2}\right)$ for $(\mathrm{G} 1,0,0)$ solid cubes to $\left(213.8 \mathrm{Kg} / \mathrm{cm}^{2}\right)$ in $(\mathrm{G} 1,60,0)$ in solid cubes. The same trend was observed hollow core concrete specimens. It was noted that use of hollow core concrete specimens with diameter $(4 \mathrm{~cm})$ decreased the compressive strength from (267.6 $\left.\mathrm{Kg} / \mathrm{cm}^{2}\right)$ for $(\mathrm{G} 1,0,0)$ to $\left(114.62 \mathrm{Kg} / \mathrm{cm}^{2}\right)$. Further increase in the diameter of hollow core from $(4 \mathrm{~cm}$ to $5 \mathrm{~cm}$ ) resulted in decrease in the compressive strength from $\left(191.24 \mathrm{Kg} / \mathrm{cm}^{2}\right)$ for $(\mathrm{G} 1,0,0) 5 \mathrm{~cm}$ specimens to $\left(108.1 \mathrm{Kg} / \mathrm{cm}^{2}\right)$ for $(\mathrm{G} 1,60,0)$.

\subsubsection{For (G 2, $0 \%$ silica fume):}

The general trend indicates that as the cement content increases from $\left(350 \mathrm{~kg} / \mathrm{m}^{3}\right.$ to $\left.450 \mathrm{~kg} / \mathrm{m}^{3}\right)$, the compressive strength increases for all specimens with and without pumice as well as specimens with and without silica fume. As the percentage of pumice increases from ( $0 \%$ to $60 \%$ ), the compressive strength decreased from $\left(393.6 \mathrm{Kg} / \mathrm{cm}^{2}\right)$ for $(\mathrm{G} 1,0$, 0 ) solid cubes to $\left(238.44 \mathrm{Kg} / \mathrm{cm}^{2}\right)$ in $(\mathrm{G} 1,60,0)$ in solid cubes. The same trend was observed hollow core concrete specimens. It was noted that use of hollow core concrete specimens with diameter $(4 \mathrm{~cm})$ decreased the compressive strength from (186.5 $\left.\mathrm{Kg} / \mathrm{cm}^{2}\right)$ for $(\mathrm{G} 1,0,0)$ to $\left(138 \mathrm{Kg} / \mathrm{cm}^{2}\right)$. Further increase in the diameter of hollow core from $(4 \mathrm{~cm}$ to $5 \mathrm{~cm}$ ) resulted in decrease in the compressive strength from $\left(146.2 \mathrm{Kg} / \mathrm{cm}^{2}\right)$ for $(\mathrm{G} 1,0,0) 5 \mathrm{~cm}$ specimens to $\left(109.55 \mathrm{Kg} / \mathrm{cm}^{2}\right)$ for $(\mathrm{G} 1,60,0)$. See Fig (15).

\subsubsection{For (G 2, $10 \%$ silica fume):}

The general trend indicates that use of silica fume by $10 \%$ increased the compressive strength in all silica fume specimens with respect to corresponding to ( $0 \%$ silica fume) specimens. This was attributed to the fact that silica fume fills the voids in the concrete even more; this was also evident from the results obtained from bulk density results. That is in addition to the effect of silica fume in increasing the cohesion in the concrete. See Fig (16).

For specimens of concrete cubes with $(10 \%$ silica fume) it was noted that as the percentage of pumice increased from $(0 \%$ to $60 \%)$ the compressive strength decreased from $\left(400.7 \mathrm{Kg} / \mathrm{cm}^{2}\right)$ for $(\mathrm{G} 1,0,0)$ solid cubes to $\left(297 \mathrm{Kg} / \mathrm{cm}^{2}\right)$ in $(\mathrm{G} 1,60,0)$ in solid cubes. The same trend was observed hollow core concrete specimens. It was noted that use of hollow core concrete specimens with diameter $(4 \mathrm{~cm})$ decreased the compressive strength from $\left(326 \mathrm{Kg} / \mathrm{cm}^{2}\right)$ for $(\mathrm{G}$ $1,0,0)$ to $\left(213.3 \mathrm{Kg} / \mathrm{cm}^{2}\right)$. Further increase in the diameter of hollow core from $(4 \mathrm{~cm}$ to $5 \mathrm{~cm})$ resulted in decrease in the compressive strength from (254.4 $\left.\mathrm{Kg} / \mathrm{cm}^{2}\right)$ for $(\mathrm{G} 1,0,0) 5 \mathrm{~cm}$ specimens to (180.6 $\left.\mathrm{Kg} / \mathrm{cm}^{2}\right)$ for $(\mathrm{G} 1,60,0)$. These results are in agreement with the bulk density results.

\subsection{Analyses of Tensile Test Result \\ 3.4.1 For (G 1) specimens}

The general trend in the tensile behavior indicates that, at $0 \%$ Pumice and $0 \%$ Silica fume $(\mathrm{G}$ $1,0,0)$ showed highest tensile ultimate failure load compared to corresponding (G 1, 0 Silica sub groups) as the content of Pumice increases from $20 \%$ to $60 \%$, the ultimate failure tensile load started to decrease gradually, which was attributed to the partial replacement of the crushed stone with Pumice. These results were in agreement with the compressive strength results. It was noted that the flexural two point load testing, indicates that the existence of the silica fume in concrete beams, slightly enhances the ultimate flexural failure load in most of the concrete beams. See Fig (17). The same trend observed in concrete specimens in G1 subgroups with $0 \%$ silica fume, was also encountered in concrete specimens in G1 subgroups with $10 \%$ silica fume, as the percentage of pumice in concrete specimens decreased from $0 \%$ to $60 \%$, the flexural strength started to decrease gradually. This was also attributed to the weak tensile strength of pumice.

\subsubsection{For (G 2) specimens}

For (G 2) with a cement content of $450 \mathrm{Kg} / \mathrm{m}^{3}$, the same trend observed in $(\mathrm{G} 1)$ specimen was encountered. In ( $\mathrm{G} 2$ ) subgroups, as the percentage of pumice increased from $20 \%$ to $60 \%$, the ultimate tensile failure load was showed a continuous decrease that was encountered in both cases with and without silica fume. These results were in agreement with the bulk density results. See Fig (18).

\subsection{Analyses of Ultra Sonic Test Result}

Ultrasonic pulse velocity was performed in all specimens under the same condition the specimens used in ultra sonic pulse velocity were concrete beams $(10 * 10 * 50) \mathrm{Cm}$.

3.5.1 For (G 1, $0 \%$ silica fume):

The general trend for $(\mathrm{G} 1)$ group with $(0 \%$ silica fume) indicates that as the percentage of pumice 
increased from $(0 \%$ to $60 \%)$ the ultra sonic pulse velocity duration increased from (106.8 to 118.05) Micro seconds. This was attributed to the existence of high porosity in pumice which reflects on increasing the duration of the signal in concrete beams. For (G 1) specimens with (10\% silica fume) the same trend discussed above was encountered in this group. The ultra sonic pulse velocity increased as the percentage of pumice increased from (107.3 to 119.1). See Fig (19).

\subsubsection{For (G 2, $10 \%$ silica fume):}

For (G 2) concrete specimens, $450 \mathrm{Kg} / \mathrm{m}^{3}$ cement was used; the results indicate compatibility with results encountered in (G 1). The ultra sonic pulse velocity readings showed that, as the percentage of pumice increased from ( $0 \%$ to $60 \%$ ) for specimens with ( $0 \%$ silica fume), the duration of the signal increased from (105.25 to 119.25) Micro seconds. This was also attributed to the high porosity of the pumice which increased the duration of the signal in concrete. The same trend was observed in concrete specimens with (10\% silica fume), as the percentage of pumice increased from ( $0 \%$ to $60 \%$ ), the ultra sonic pulse velocity increased from (105.35 to 131.25) Micro seconds. See Fig (20).

\section{Conclusion}

In this chapter a summary of conclusion reached from the experimental program are reported in what follows:-

1- As the percentage of pumice increases from $(0 \%$ to $60 \%$ ) the slump value decreases that was encountered in all groups due to rough surface texture of pumice and high absorption capacity of pumice.

2- The effect of using hollow cores plays more effective roles in reducing the bulk density then replacement of crushed stone with pumice. Although both of them participate in reduction of bulk density. 3- Although increase in percentage of pumice and existence of hollow core reduces the compressive strength. On the other hand, increase in silica fume and increase of cement content increases the compressive strength.

4- Ultra sonic pulse velocity indicates that, increase in the percentage of pumice increases the duration of ultra sonic pulse thus decreases the velocity of signal in concrete which is compatible with compressive strength results.

\section{References}

[1] Khandaker M.A. Hossain and Mohamed Lachemi, "Mixture Design, Strength, Durability, and Fire Resistance of lightweight Pumice Concrete"ACI Materials Journal t, Title. No. 104-M49, SeptemberOctober (2007).

[2] Wang Lijiu, Zhang Shuzhong, Zhao Guofan, "Investigation of the mix ratio design of lightweight aggregate concrete". Cement and Concrete Research, $35,931-935$ (2005)

[3] Ryan Henkensiefken , Javier Castro, Dale Bentz , Tommy Nantung, Jason Weiss, "Water absorption in internally cured mortar made with water filled light weight aggregate", Cement and Concrete Research Vol.39 883-892 (2009)

[4] S.Malek, A.Mohammadjafari, S.Nazari, and S.P.Seyy"Producing of lightweight concrete using pumice and mineral aggregates and comparing the curing process of Autoclave with saturated condition" Journal of Applied sciences 10(11):9961000, ISSN: 1812, (2010).

[5] Al-Khaiat, H., and Haque, M.n., "Effect of Initial Curing on Early Strength and Physical Properties of a Light Weight Concrete, "Cement and Concrete Research, Vol.28 No.6, pp. 859-866 (1998).

[6] Lu-shu, K., Man-qing, Xing-Sheng, Yun-xiu, "Research on Several Physico-Mechanical Properties of Light weight Aggregate Concrete," International Journal of Light Weight Concrete, Vol. 2 No.4, pp.185-191(1980).

[7] Amir Elsharief, Menashi D. Cohen, Jan Olek "Influence of light weight aggregate on the microstructure and durability of mortar" Cement and Concrete Research” Vol. 35 1368-1376 (2005).

[8] Mauricio Lopez, Lawrence F.khan and Kimberly E. Kurtis, "Creep and Shrinkage of high Performance Light weight Concrete". ACI materials Journal, Vol.101-M44 pp. 391-399 (October 2004).

[9] D.Saradhi Babu, K. Ganesh Babu, T.H. Wee, "Properties of light weight expanded polystyrene aggregate concretes containing fly ash". Cement and concrete Research vol. 35, 1218-1223 (2005).

[10] S.Anzari, S.P.Seyyedi "Producing lightweight concrete using pumice and mineral Aggregate" Journal of applied sciences Vol. 10(11):P.P. 996_1000, (2010).

[11] R. Sri Ravindrarajah, A.J. Tuck, "Properties of hardened concrete containing treated expanded polystyrene beads, "Cement and Concrete Composites”, Vol. 16 273-277, (1994).

[12] Hossain, K.m., A., 'Properties of Volcanic Scoria Based Light weight Concrete", Magazine of Concrete Research, Vol. 56, No.2, pp. 111-120, (2002). 


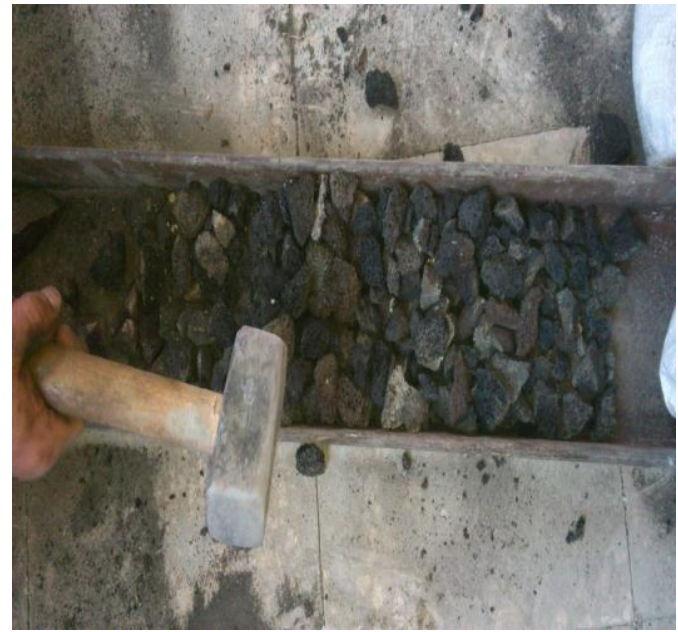

Fig (1) Manual breakdown of pumice

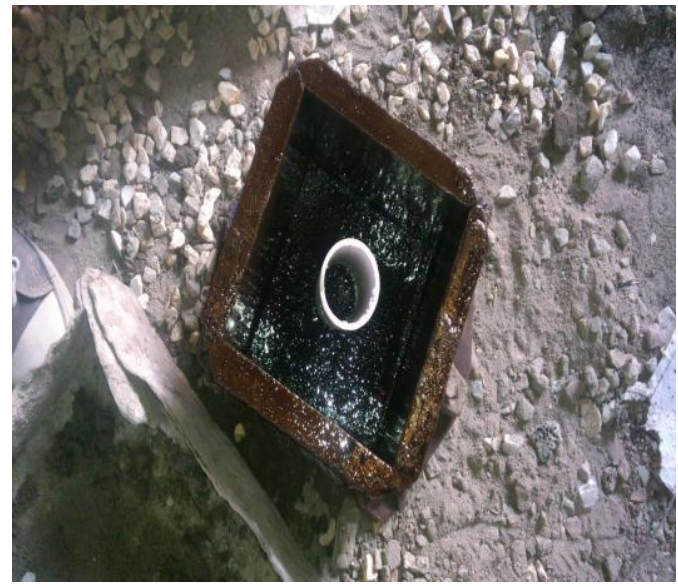

Fig (3) Preparation of hollow core in concrete cubes

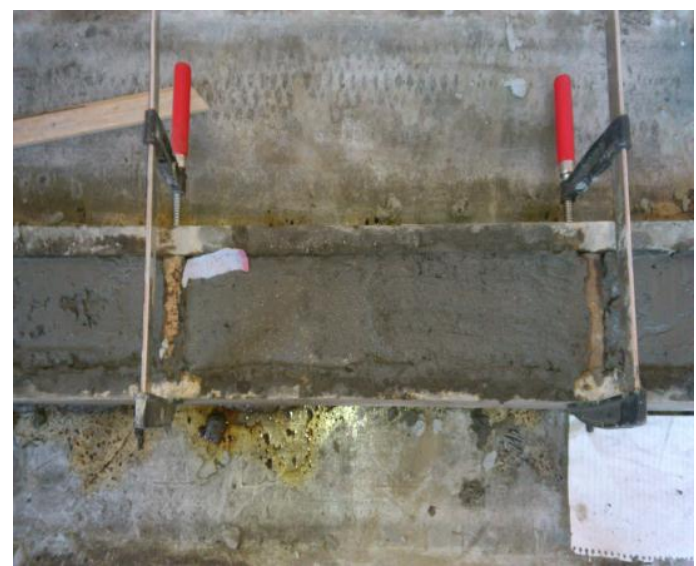

Fig (5) Concrete beams during casting

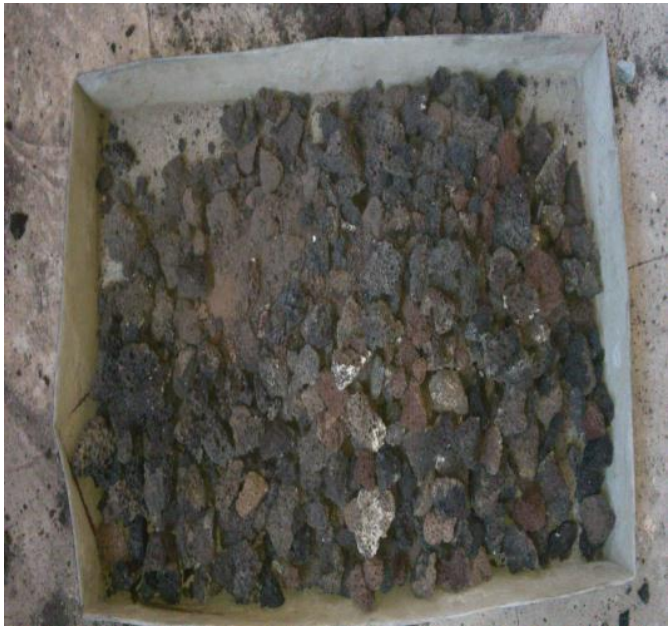

Fig (2) Pumice prepared for mixing

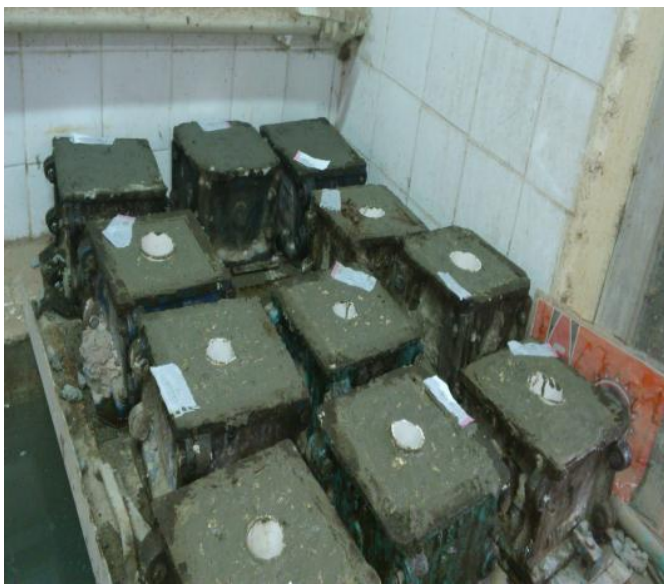

Fig (4) Hollow core in concrete cubes after casting

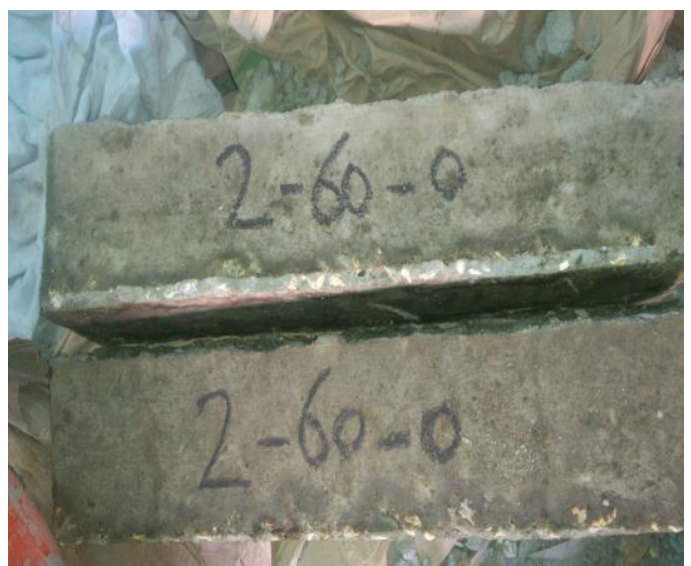

Fig (6) Concrete beams after casting and coding 

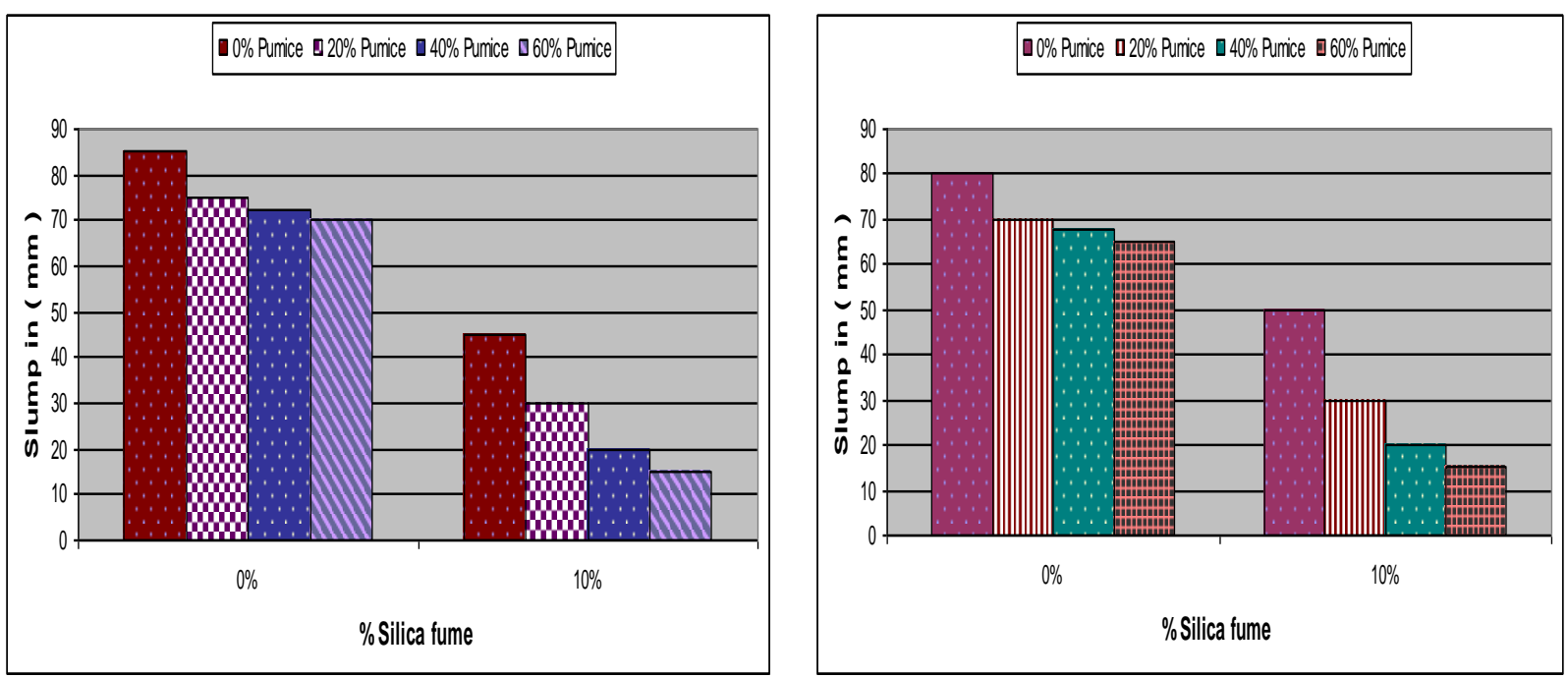

Fig (7) Slump value results for group 1 with $0 \% \& 10 \%$ S. F. $\quad$ Fig (8) Slump value results for group 2 with $0 \%$ \& 10\% S. F.
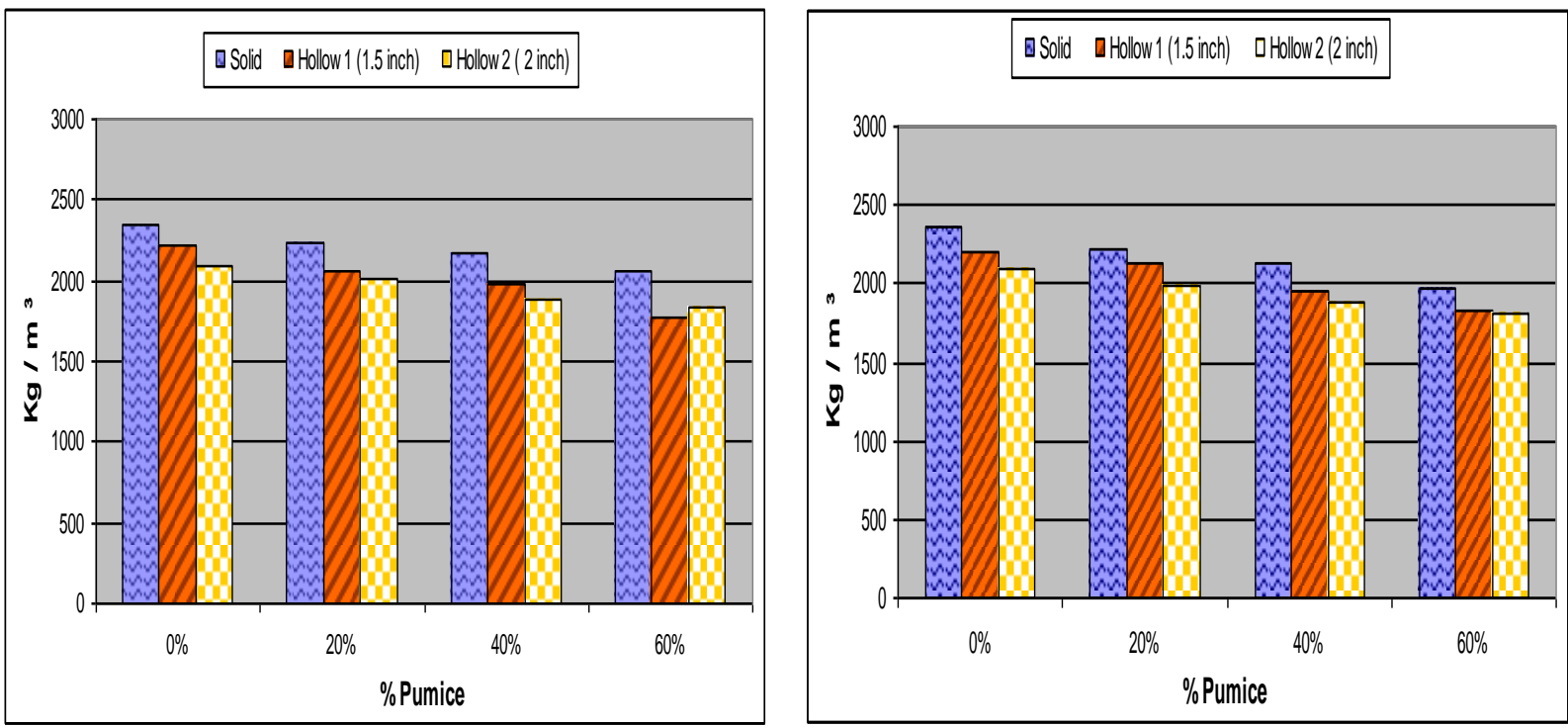

Fig (9) Bulk density value result for (G 1,0\% Silica fume)

Fig (10) Bulk density value result for (G 1, 10\% silica fume) 

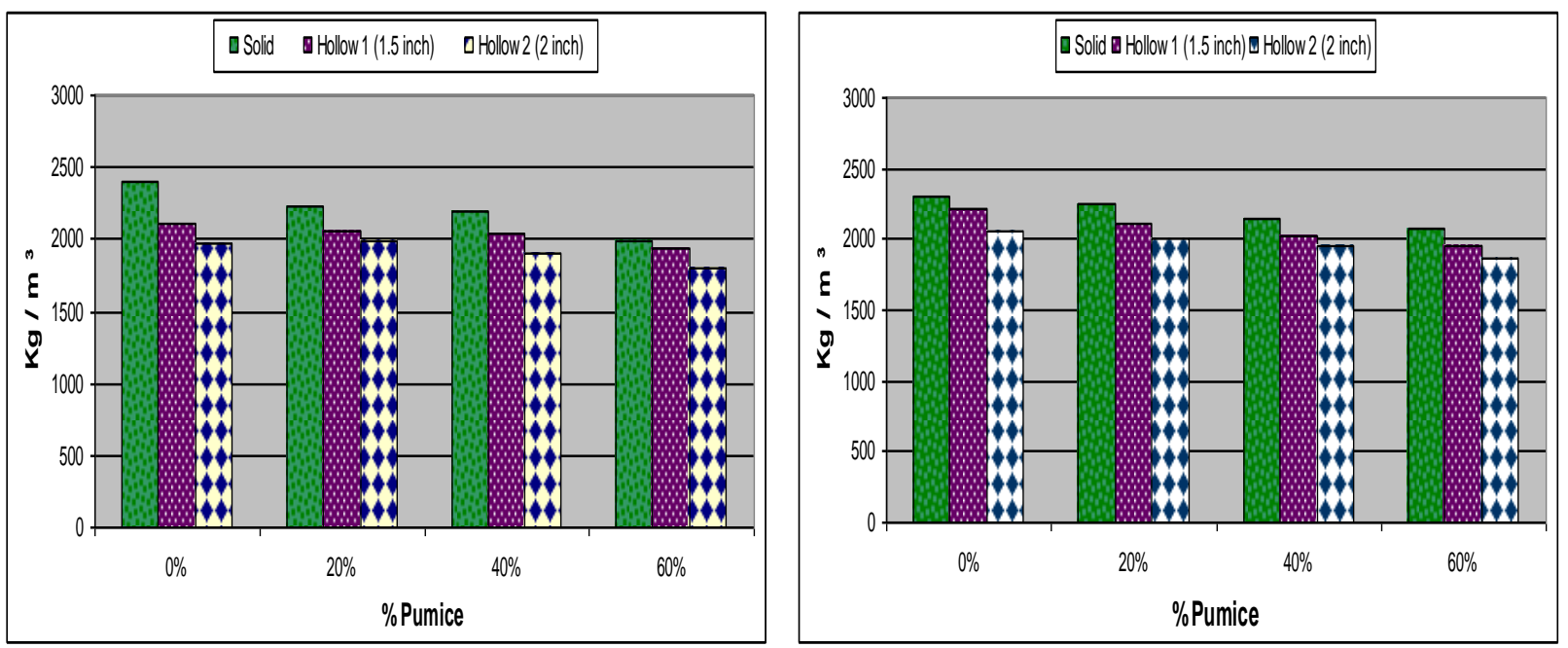

Fig (11) Bulk density value result for (G 2, 0\% silica fume)

Fig (12) Bulk density value result for (G 2, $10 \%$ silica fume)

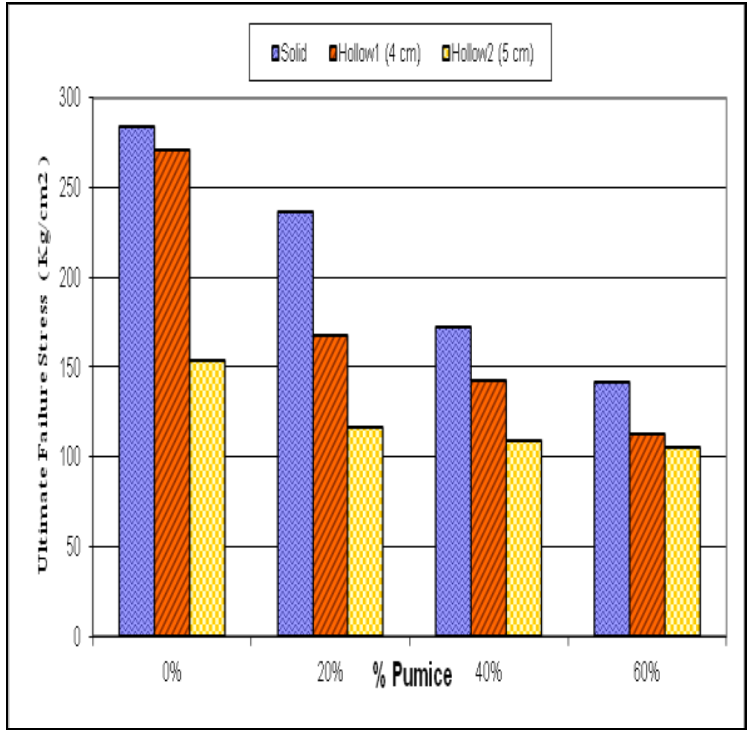

Fig (13) compression value result for ( $\mathrm{G} 1,0 \%$ silica fume)

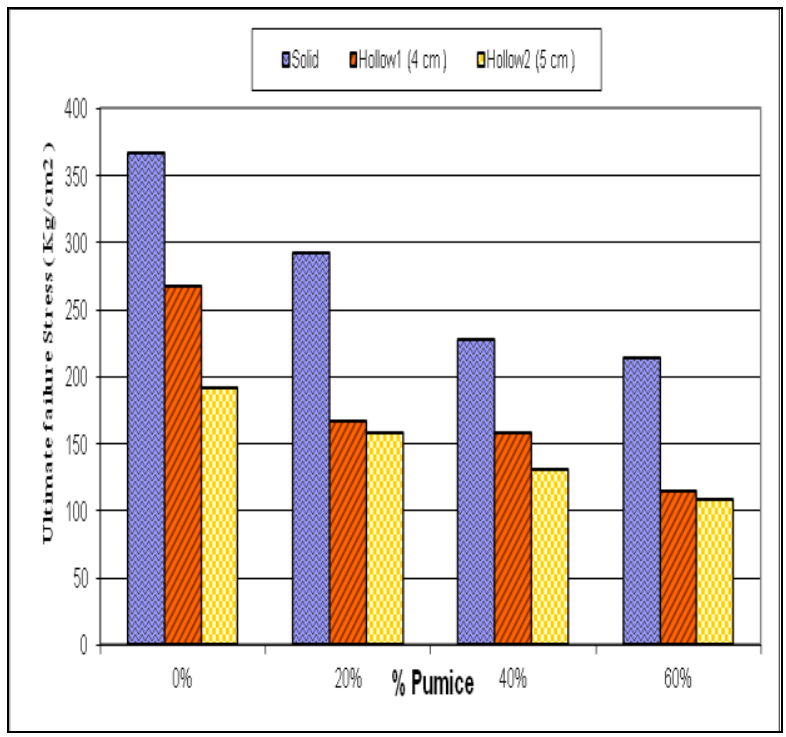

Fig (14) compression value result for (G 1, 10\% silica fume) 
Amr A. Gamal " Hollow core in light weight concrete with pumice and silica fume"
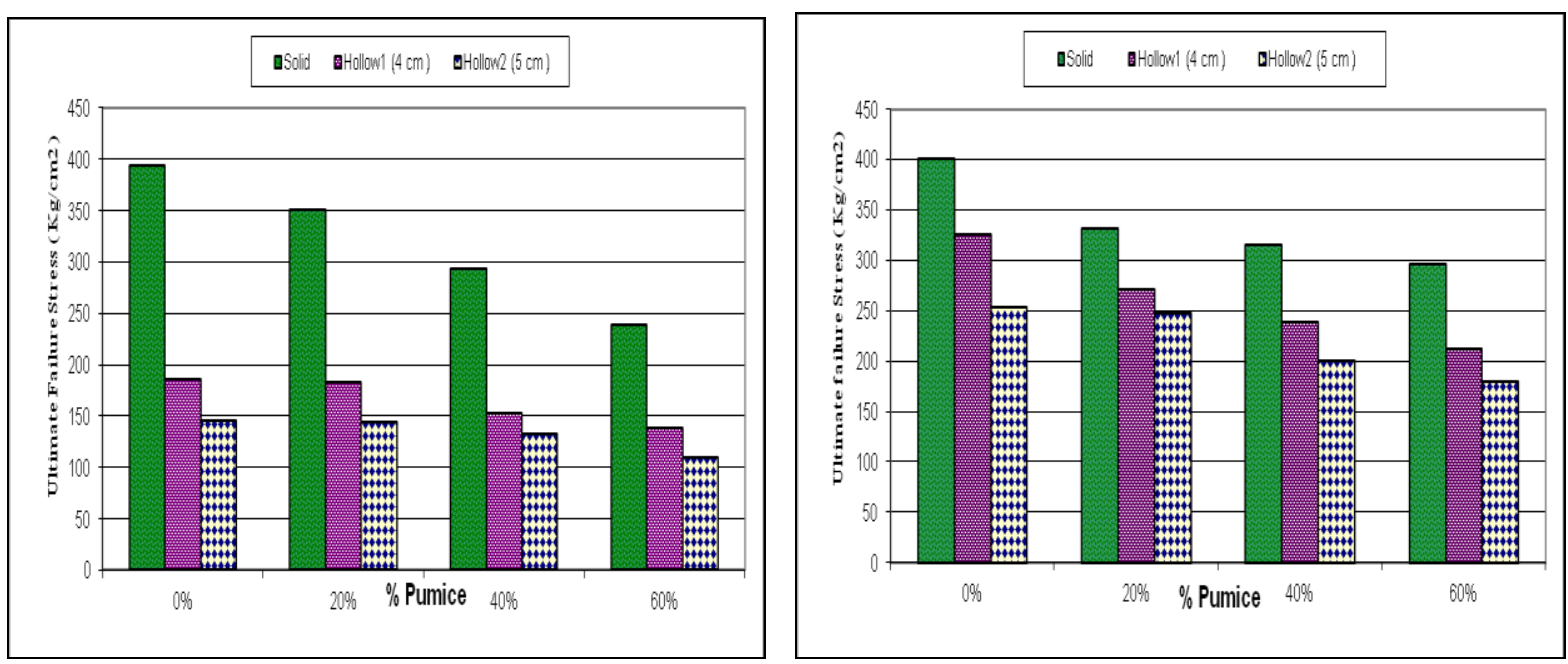

Fig (15) compression value result for (G 2, 0\% silica fume) Fig (16) compression value result for (G 2, 10\% silica fume)

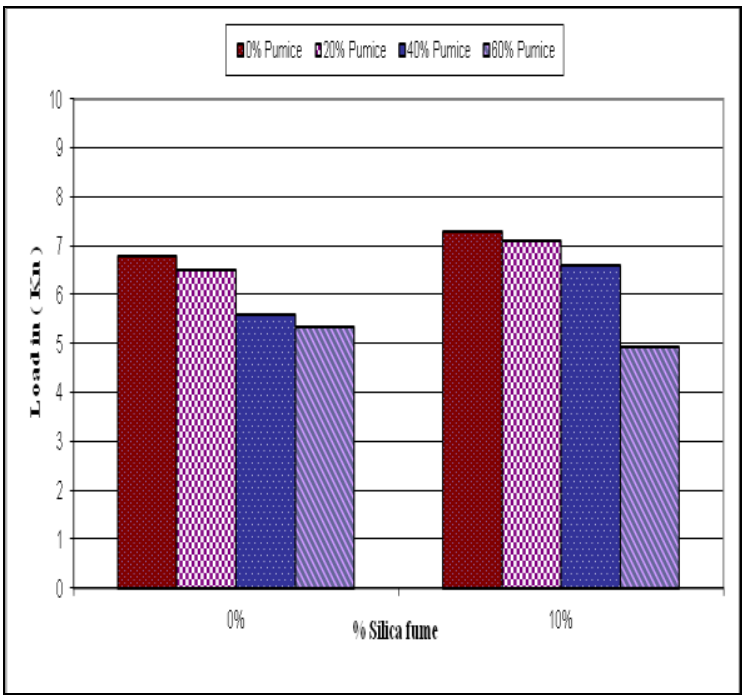

Fig (17) Tensile strength value result for group 1

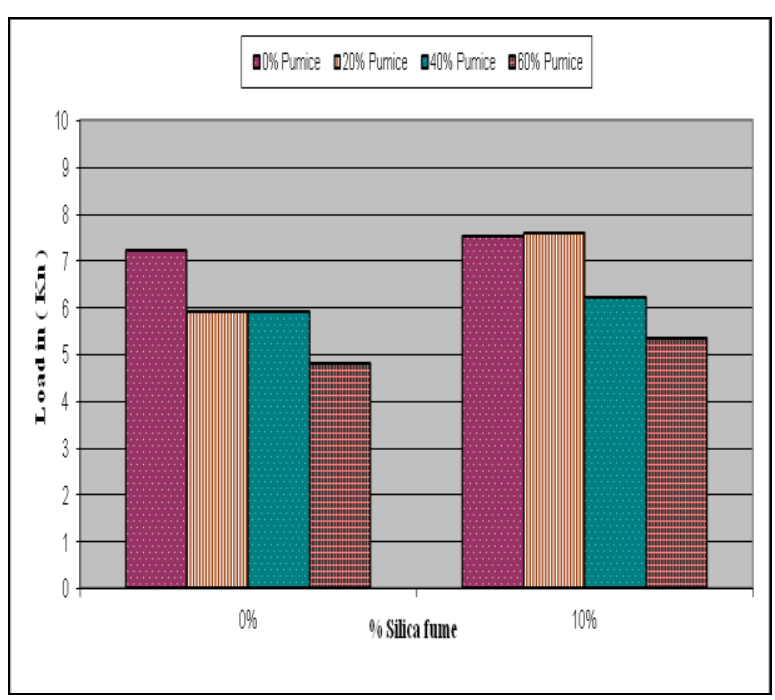

Fig (18) Tensile strength value result for group 2 


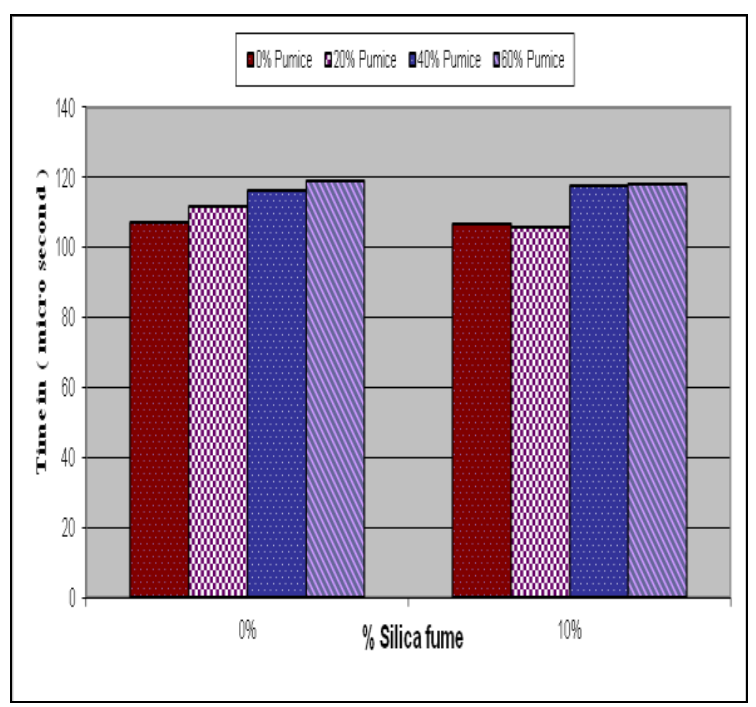

Fig (19) Ultra sonic pulse velocity result for group 1

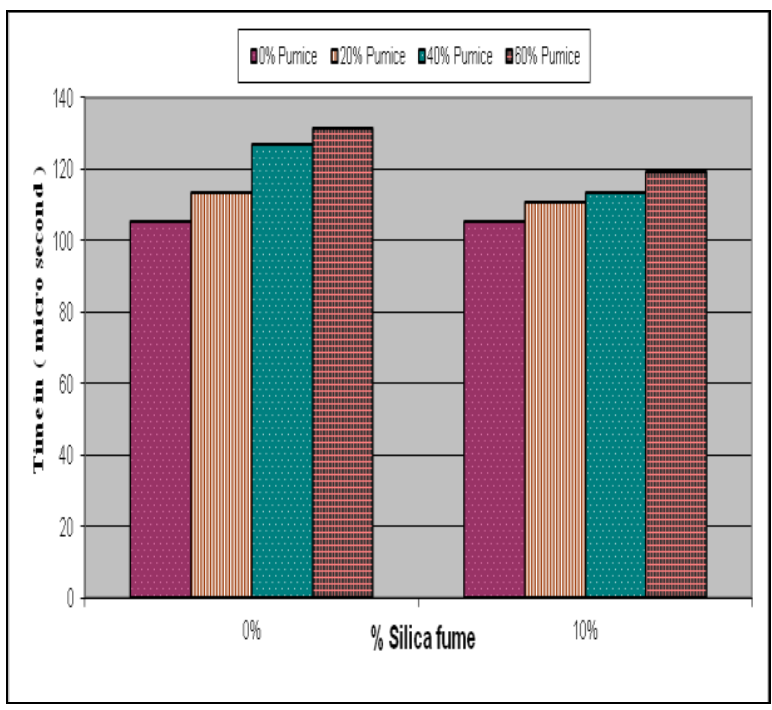

Fig (20) Ultra sonic pulse velocity result for group 2

Table (1): Mix Proportions for concrete specimens with pumice and silica fume in phase (1) and phase (2)

\begin{tabular}{|c|c|c|c|c|c|c|c|}
\hline Group & Cement $\left(\mathrm{Kg} / \mathrm{m}^{3}\right)$ & C.Agg $\left(\mathrm{kgm}^{3}\right)$ & Sand $\left(\mathrm{kg} / \mathrm{cm}^{3}\right)$ & Water $\left(\mathrm{Kg} / \mathrm{m}^{3}\right)$ & W/C & $\begin{array}{l}\text { Pumice } \\
\left(\mathrm{Kg} / \mathrm{m}^{3}\right)\end{array}$ & $\begin{array}{c}\text { Silica } \\
\text { Fume }\left(\mathrm{Kg} / \mathrm{m}^{3}\right)\end{array}$ \\
\hline \multicolumn{8}{|l|}{ PHASE 1} \\
\hline G $1-0-0$ & 350 & 1200 & 700 & 192.5 & 0.55 & $\mathbf{0}$ & $\mathbf{0}$ \\
\hline G $1-20-0$ & 350 & 960 & 700 & 192.5 & 0.55 & 80 & $\mathbf{0}$ \\
\hline G $1-40-0$ & 350 & 720 & 700 & 192.5 & 0.55 & 160 & $\mathbf{0}$ \\
\hline G $1-60-0$ & 350 & 480 & 700 & 192.5 & 0.55 & 240 & $\mathbf{0}$ \\
\hline \multicolumn{8}{|l|}{ Spec with S.F } \\
\hline G $1-0-10$ & 350 & 1200 & 700 & 192.5 & 0.55 & 0 & 35 \\
\hline G $1-20-10$ & 350 & 960 & 700 & 192.5 & 0.55 & 80 & 35 \\
\hline G $1-40-10$ & 350 & 720 & 700 & 192.5 & 0.55 & 160 & 35 \\
\hline G $1-60-10$ & 350 & 480 & 700 & 192.5 & 0.55 & 240 & 35 \\
\hline \multicolumn{8}{|l|}{ PHASE 2} \\
\hline G 2-0-0 & 450 & 1200 & 700 & 247.5 & 0.55 & 0 & 0 \\
\hline G 2-20-0 & 450 & 960 & 700 & 247.5 & 0.55 & 80 & 0 \\
\hline G $2-40-0$ & 450 & 720 & 700 & 247.5 & 0.55 & 160 & $\mathbf{0}$ \\
\hline G 2-60-0 & 450 & 480 & 700 & 247.5 & 0.55 & 240 & 0 \\
\hline \multicolumn{8}{|l|}{ Spec with S.F } \\
\hline G 2-0-10 & 450 & 1200 & 700 & 247.5 & 0.55 & 0 & 45 \\
\hline G $2-20-10$ & 450 & 960 & 700 & 247.5 & 0.55 & 80 & 45 \\
\hline G $2-40-10$ & 450 & 720 & 700 & 247.5 & 0.55 & 160 & 45 \\
\hline G $2-60-10$ & 450 & 480 & 700 & 247.5 & 0.55 & 240 & 45 \\
\hline
\end{tabular}


Amr A. Gamal " Hollow core in light weight concrete with pumice and silica fume"

Table (2) Test Program Results for Groups in Phase 1 and Phase 2

\begin{tabular}{|c|c|c|c|c|c|c|c|c|c|}
\hline & & Bulk D & ity Test & /m3) & Ultimate & $\begin{array}{l}\text { npressior } \\
(\mathrm{Kg} / \mathrm{cm}\end{array}$ & lure load & $\begin{array}{l}\text { Ultimate } \\
\text { tensile }\end{array}$ & $\begin{array}{l}\text { Ultrasonic } \\
\text { pulse }\end{array}$ \\
\hline Group & $\begin{array}{c}\text { Slump } \\
\text { Test in } \\
(\mathrm{mm})\end{array}$ & $\begin{array}{l}\text { Solid } \\
\text { cubes }\end{array}$ & $\begin{array}{c}\text { Hollow } \\
\text { cubes } \\
(4 \mathrm{~cm})\end{array}$ & $\begin{array}{l}\text { Hollow } \\
\text { Cubes } \\
(5 \mathrm{~cm})\end{array}$ & $\begin{array}{l}\text { Solid } \\
\text { cubes }\end{array}$ & $\begin{array}{l}\text { Hollow } \\
\text { cubes } \\
(4 \mathrm{~cm})\end{array}$ & $\begin{array}{l}\text { Hollow } \\
\text { cubes } \\
(5 \mathrm{~cm})\end{array}$ & load (Kn) & (Micro sec) \\
\hline G 1-0-0 & 85 & 2346.7 & 2216.3 & 2085.9 & 284.4 & 270.7 & 154.3 & 6.8 & 107.3 \\
\hline G 1-20-0 & 74 & 2237 & 2065.2 & 2005.9 & 236.5 & 167.4 & 117 & 6.5 & 112 \\
\hline G 1-40-0 & 72 & 2171.8 & 1982.2 & 1887.4 & 172.6 & 143.1 & 109.3 & 5.59 & 116.2 \\
\hline G 1-60-0 & 70 & 2059.3 & 1774.9 & 1831.1 & 141.7 & 113.3 & 105.3 & 5.35 & 119.1 \\
\hline G 1-0-10 & 46 & 2361.5 & 2198.5 & 2094.8 & 367 & 267.6 & 191.24 & 7.3 & 106.8 \\
\hline G 1-20-10 & 31 & 2222.2 & 2121.5 & 1991.1 & 292.1 & 166.2 & 157.1 & 7.1 & 106.05 \\
\hline G $1-40-10$ & 20 & 2130.4 & 1955.6 & 1881.5 & 227.6 & 157.65 & 130.9 & 6.6 & 117.55 \\
\hline G 1-60-10 & 15 & 1964.4 & 1828.2 & 1804.4 & 213.8 & 114.62 & 108.1 & 4.95 & 118.05 \\
\hline G 2-0-0 & 80 & 2397 & 2112.6 & 1973.3 & 393.6 & 186.5 & 146.2 & 7.2 & 105.35 \\
\hline G 2-20-0 & 68 & 2228.2 & 2053.3 & 1985.2 & 350.3 & 183.37 & 144.9 & 5.9 & 116.8 \\
\hline G 2-40-0 & 67 & 2201.5 & 2035.6 & 1902.2 & 293.8 & 153.2 & 133.4 & 5.9 & 127.05 \\
\hline G 2-60-0 & 65 & 1991.1 & 1931.9 & 1807.4 & 238.44 & 138 & 109.55 & 4.8 & 131.25 \\
\hline G 2-0-10 & 52 & 2308.2 & 2222.2 & 2062.2 & 400.7 & 326 & 254.4 & 7.5 & 105.25 \\
\hline G 2-20-10 & 30 & 2251.9 & 2115.6 & 2011.9 & 331.8 & 271.33 & 248.5 & 7.6 & 110.9 \\
\hline G 2-40-10 & 21 & 2148.2 & 2014.8 & 1961.5 & 315.6 & 238.6 & 201.3 & 6.2 & 113.35 \\
\hline G 2-60-10 & 15 & 2074.1 & 1949.6 & 1860.7 & 297 & 213.3 & 180.6 & 5.325 & 119.25 \\
\hline
\end{tabular}

